\title{
The Introduction of Total Quality Management in Greek Public Administration: The Case of Common Assessment Framework (C.A.F.).
}

\author{
Stamatina Giannakopoulou \\ BSc in Management, MBA, PhD student \\ University of Peloponnese \\ Faculty of Human Movement and Quality of Life \\ Department of Sports Organization and Management \\ E.\&S. Valiotis Av. \& Plateon Street \\ 23100 Sparti - Greece \\ Panagiotis Alexopoulos \\ Dean of the Faculty of Human Movement and Quality of Life Sciences \\ University of Peloponnese \\ E.\&S. Valiotis Av. \& Plateon Street \\ 23100 Sparti - Greece
}

\begin{abstract}
In this work we explore the introduction of Total Quality Management tools in Greek Public Sector. More specifically we researchthe use of Common Assessment Framework (CAF), which is an easy, friendly and economic tool, in order to the increase the effectiveness, efficiency and productivity of the Greek Public Administration. For that reason, an exploratory research has been developed, using the case study method in a Greek Public Organization to investigate the above objectives. The article is organized as follows: In the first section we state the problem, aims and objectives. In the second section we introduce TQM/CFA tools for the Public Sector. In the third section we discuss the implementation of CAF in the Ministry of Administrative Reform and Electronic Governance, the outcomes of CAF implementation as well its usefulness. We end with the conclusions.
\end{abstract}

Key Words: Total Quality Management, Public Administration, Common Assessment Framework (C.A.F.)

\section{Introduction}

A new tendency in management, which could significantly contribute to the elimination of many insufficiencies and the change of culture in the Greek Public Administration is Total Quality Management (TQM). TQM is constituted by practices and methods which are implemented in public and private organizations and aim to satisfy the customercitizen and strengthen human resources. The Common Assessment Framework (CAF) is a simple, easy to use and inexpensive tool of self- assessment of the performances of public organizations. CAF provides the organizations the opportunity to trace their strengths and weaknesses with a self-assessment process. CAF offers the capability of realizing a thorough record of the internal and external environment of a public organization, thus contributing to the understanding of Public Sector's functioning.

The general aim of this research is to highlight the benefits of TQM implementation, and specifically CAF's, in the Greek Public Sector. Particularly, the objectives of the present research are the following:

- To review and analyze TQM models and theories used in the public sector, focusing on CAF implementation.

- To develop an appropriate methodology in order to explore public servants' views (through recording their experiences), about the effectiveness of CAF in the Greek Public Administration.

- To collect data from public servants about the usefulness of CAF in the Greek Public Administration.

- To analyze and discuss the data.

- To demonstrate how CAF could be effective to reduce the insufficiencies of the Greek Public Sector in a crucial period. 


\section{TQM/ CAF in public sector}

The implementation of TQM does not automatically mean its successful adoption. Except from the existence of an adequate organization culture, where communication between employees and employers will be enforced, the need for change is also required. If a need for change is crucial and the management waits for fast and direct results, then the introduction of TQM systems won't bring success (Hitiris, 1990). However, if the managers understand this need, the implementation of TQM tools will also lead to the change of organizational culture and its successful implementation (Psychogios, 2010).

An integrated TQM system in order to be well implemented should include:

- The education and development of human potential.

- The way of organizing the total effort.

- The systematic measurement of the basic for the customer quality rates.

- The constant effort from the employees and the managers to improve quality.

TQM in contrast to other managerial approaches which emphasize on one main characteristic of effectiveness, has a combined character and covers all the major competitiveness indicators and a vast range of methods and product and services improvement techniques. It is obvious, that during TQM implementation, employees will produce products and provide services of high quality, only when the sense of quality has been assimilated by all the members of the organization. Therefore, for its success, TQM ideas and principles should be adopted by the entirety of the organization, meaning that it starts from the top (leadership) and ends to the last employee.

The Common Assessment Framework (CAF), which is a TQM tool and is inspired by the EFQM model, is dressing mostly to public organizations and has been designed in such a form that its use will be easy and simple for all the institutions in central and local level (Passas, 2010). CAF is a friendly tool, which helps the European public organizations to use TQM techniques and improve their performances. Its use provides to organizations a framework of principles and procedures, which contribute to the continuous administrative improvement, while it offers an assessment based on real facts, chances of progress recognition, employee empowerment, and emergence of good practices (CAF, 2007). At the same time, CAF assists organizations using self-assessment with the involvement of all the employees, in developing an improvement plan based on the results of the assessment and in implementing specific designed actions (Dearing et al, 2006).

CAF has four main goals:

- $\quad$ To introduce the principles of TQM in Public Administration and to lead through self assessment to a complete circle of quality (Planning, Execution, Control, Feedback).

- To exist as a useful and friendly tool for public organizations, so that they improve their effectiveness and efficiency.

- $\quad$ To act as a "bridge" among several models used in quality management.

- $\quad$ To facilitate bench learning between public sector organizations (Rickards, 2013).

CAF has nine (9) assessment criteria, which refer to the basic aspects of organizations. Criteria one to five (1-5), are called Enablers and deal with the managerial practices of an organization. They determine what an organization does and how it approaches its tasks to achieve the desired results (CAF, 2013). Criteria six to nine (6 -9) are Results in the fields of citizens, people, social responsibility, and performance. Each criterion has several sub criteria. The 28 sub criteria refer to the main issues that are necessary for the assessment of the organization. According to CAF, the results of an organization in the fields of performance, citizens and society depend on leadership, strategy, human resources, partnership development and resources, and finally administrative procedures. The structure of CAF is given to the following figure.

Enablers (criteria 1-5), are related to the preconditions of function of a public organization, meaning that they define what a public organization does and in what way in order to achieve the desired results. Results (criteria 6-9), analyze the level of satisfaction of personnel, customers- citizens and society, from the functions of the organization (enablers). Therefore, the first criteria are preconditions for the achievement of positive results (second criteria).

More specifically the criteria are analyzed as follows:

\section{- $\quad$ Criterion 1: Leadership}

Leadership refers to the way through which supervisors form the mission of the organization and facilitate its achievement, in order to contribute to the realization of the vision of the organization (Kotler, 1999). 
The role of the leader is very important in CAF, since the leader inspires, persuades, motives and supports employees through the appropriate communication, thus ensuring the development and the effective implementation of the administrative system.

\section{- $\quad$ Criterion 2: Strategy and Planning}

This criterion assesses how the organization combines effectively its several activities and defines its overall performance. Strategy is the general route that an organization follows in order to respond to its mission and reach its vision, while planning is the process through which the organization predefines what wants to achieve in the future, in what ways and means and when (Bourantas, 2002). Criterion 2, investigates the ability of institutions to be adjusted in changes and implement effectively their target setting, based on a designed strategic planning (Passas, 2010).

\section{- $\quad$ Criterion 3: Human Resources}

The third criterion concerns the assessment of human resources of an organization. The employees are the most important asset of an organization and constitute a crucial factor of success and achievement of a competitive advantage (Kanellopoulos, 2002). CAF investigates if the organization manages, develops, sets free the knowledge and capabilities of employees, so that it could support its policy, strategy and the effective function of its human resources. This criterion assesses the ability of the organization to assure adequate and sufficient personnel, the care for the safety and health of employees, the provision of educational programs of reeducation and the creation of policies of intakes and promotions with objective criteria (CAF, 2007).

\section{- $\quad$ Criterion 4: External Partnership and Resources}

This criterion refers to the way through which an organization plans and manages its external partnership and its internal resources, in order to support its policy, strategy and the effective function of its processes (Passas, 2010). It includes the relations of the organizations with representatives of private and public sector and its resources (money, technology, facilities) for the successful achievements of its goals.

\section{- $\quad$ Criterion 5: Administrative processes}

The fifth criterion refers to the way that a public service manages, improves and develops its processes in order to form innovations, support its strategy and satisfy its customers- citizens. It assesses the procedures which create added value for citizens, the satisfaction of them after the realization of their transactions and the dealt with any problems or complaints appear (CAF, 2007).

\section{- $\quad$ Criterion 6: Results for customers- citizens}

This criterion refers to the outcomes that a public organization achieves towards the satisfaction of its customers. The factors of their satisfaction are the level of access to public services, the provision of quality services, the behavior of public servants etc. (Passas, 2010).

\section{- $\quad$ Criterion 7: Results for human resources}

These are the results of the organization related to the capabilities, motives, satisfaction and performance of human resources. They refer to the perception of employees for the organization, its mission, the working environment, the provision of services and the development of their abilities. Briefly, the criterion examines if the employees are satisfied from the organization as a whole.

\section{- $\quad$ Criterion 8: Results for Society}

Criterion 8 assesses the outcomes that a public service achieves towards the satisfaction of expectations and needs of the local, national and international community (Passas, 2010).

\section{- $\quad$ Criterion 9: Key Performance results}

The key performance results include the achievements of the organization, concerning its strategy and planning. There are strictly connected with the measurement of efficiency, the achievement of goals, and the effectiveness of its internal function (CAF, 2007). 


\section{The implementation of CAF in the Ministry of Administrative Reform}

The mission of the Ministry, according to its official website is the constant, methodic and continuous effort for the provision of better services ${ }^{1}$. In this framework, in 2007, the leadership of the Ministry decided to implement a new TQM tool, CAF, in one of its Directorates, the Directorate of Human Resources, in order to gain the outcomes of such a tool. According to most participants, the main reasons for this implementation were the upgrade of functions of the Directorate, and the diagnosis of the strengths and weaknesses of the organization.

"CAF is an instrument of Total Quality Management, which is a simple and friendly model in order to acquire a complete image about the way of function of an organization. For that reason, the top management decided to apply CAF. It was an opportunity to find the strengths and weaknesses of the Directorate and thus maintain them or improve them. This model seemed to be appropriate for the upgrade of its functions and for the creation of a new Directorate more developed with a well informed leadership and strong human resources" (R.3).

Based on specific reports and administrative documents, the task started by creating a CAF team, consisted by 13 members: those who assess the criteria and those who design actions ${ }^{2}$. There had been an effort to create a team with highly qualified employees. Five of the thirteen members, were heads of departments in the Ministry, which is a quite good proportion in the total number of participants. This indicates the effort of the leadership to implement effectively this new TQM tool. It is obvious that the contribution of higher echelons in the assessment procedure is important, since they constitute the link between the political leadership and the administrative hierarchy. Therefore, their experience, knowledge and range of supervision could guarantee an effective implementation of CAF.

Each team had a leader, who was responsible to monitor the organization of the task.

After the creation of these groups, each participant had to be informed and educated about the CAF, in order to be able to implement it right. The preparation of the members had been made through specialized seminars organized by the National School of Public Administration and through the distribution of the official CAF driver, as it is presented by the European Institute of Public Administration (EIPA). Some of the participants, in order to be more aware of this tool, searched themselves, for their personal interest, to find more information about CAF.

"The preparation made through seminars realized in the National Centre of Public Administration, and through the driver of CAF implementation. However, some of the members of the assessment team made a personal searching in order to learn more and be more effective in this implementation (R.2)".

The first step for the implementation of CAF, was the completion of some questionnaires concerning the nine criteria, by the employees of the Ministry, which would be useful for the assessment of the criteria.

"First of all we used the questionnaires presented in the guide of CAF implementation. These questionnaires, 50 in number, were distributed to the employees of our Ministry. For the scoring of each criterion we took under consideration the answers of questionnaires and all the necessary documents, such as laws, presidential decrees and administrative documents". (R.3)

By this way, the self-assessment process starts, since the employees of the Ministry are those who will define what are the advantages and disadvantages of the Directorate's function. Furthermore, the questionnaires were anonymous, so that the respondents feel free to answer sincerely all the questions.

After the collection of the questionnaires, a report was made by the assessment team, writing down all the strengths and weaknesses of the Directorate per criterion and then scoring each criterion, in a scale of 0-100 points, based not only on the answers of the employees, but also on secondary data, such as legislation, regulatory acts, administrative documents, and on their personal beliefs.

"We based on the appropriate documents (legislation, administrative documents etc.) and on questionnaires answered by the employees of the Ministry concerning questions for each criterion and sub criterion"(R.10).

${ }^{1}$ www.gspa.gr(last visit: 04/02/2015)

${ }^{2}$ Administrative document: $\Delta \mathrm{I} \Delta \mathrm{K} / \Phi .39 \mathrm{~B}^{\prime} / 1 / 6564 / 14.3 .2007$ 
According to the assessment report, the total scoring of the criteria was the following:

\begin{tabular}{|l|l|l|l|l|l|l|l|l|l|l|}
\hline Criteria & 1 & 2 & 3 & 4 & 5 & 6 & 7 & 8 & 9 & AVER. \\
\hline Scores & 67,5 & 66 & $\mathbf{7 5}$ & 73 & 68,3 & 70 & 75 & 70 & $\mathbf{6 2 , 5}$ & 69,7 \\
\hline
\end{tabular}

Where, as analyzed in previous chapters, Cr. 1 is Leadership, Cr. 2 is Strategy and Planning, Cr. 3 is Human Resources, Cr. 4 is Cooperation and Resources. Cr. 5 is Procedures, Cr. 6 is Outcomes for the customer/ citizen, Cr. 7 is Outcomes for Human Resources, Cr. 8 is Outcomes for the Society and Cr. 9 is Key Performance Results.

From the above scores found in reports, it is obvious that the highest score is in Human Resources and the lowest in key performance results. Human Resources criterion is considered to be the most important criterion, since the mission of the Directorate is the service of the employees of the Ministry. The Directorate tries to have strong human resource forces, and therefore the implementation of CAF would be a start for the strengthening of bonds between employees and the cultivation of a team spirit.

"This model seemed to be appropriate for the upgrade of its functions and for the creation of a new Directorate more developed with a well-informed leadership and strong human resources" (R.3).

According to administrative documents, criterion 9 (key performance results) had the lowest scoring, mostly because of the lack of the appropriate material/ technical infrastructure. The other criteria had similar scorings, with an average of $69,7 \%$, a good scoring for a new implementation tool, which is justified in the following response.

"In some cases we had disagreed about the scores, since some of the members wanted to show a good image and score high" (R.9).

The scoring of the criteria was the most difficult part of the CAF implementation. The assessment team found difficulties in understanding the content of the criteria and the way of scoring, because of the lack of time for further education and information, since it was the first time that a TQM had been implemented in the Ministry.

"Because of the little time we had to be prepared, it was difficult for us to well interpret each criterion and sub criterion and to understand the way of scoring" (R.9).

After the scoring process, the second team, based on the reports of the assessment team, tried to design actions per criterion, so that the strengths of each criterion would be reinforced and the weaknesses would be eliminated. According to most respondents, the designed actions, were general and without any specific target, because of the diagnostic character of this first implementation.

"The designed actions that we proposed had a general significance" (R.5).

"The designed actions had a more general character" (R.7).

"CAF implementation was something new for us, so I believe that it had a more diagnostic character" (R.3).

According to the report of the designed actions, some of the proposed actions were: employees' motivation, the creation of a communicative policy, the improvement of the communication profile of the Directorate, the provision of incentives to employees so that they develop initiatives in their daily work etc. Therefore, the designed actions had a character of general propositions, since the participants had little time to design these actions. This first implementation was an effort of diagnosing the present status of the Directorate, without posing specific measures of facing the existed problems or dysfunctions. However, this self- diagnosis process contributed to the tracking of those strengths that the Directorate would be more effective and productive. This helped the Directorate enrich its existing procedures the next years, for the attainment of its functions. The implementation of CAF is presented and summarized in the following table, according to the reports of the assessment team and the team of designed actions. 


\begin{tabular}{|c|c|c|c|}
\hline Criteria & Strengths (+) & Weaknesses (-) & Designed Actions \\
\hline 1. Leadership & $\begin{array}{l}\text { Unification, form of } \\
\text { mission and vision, } \\
\text { employees orientation }\end{array}$ & $\begin{array}{l}\text { Lack of TQM } \\
\text { instruments and } \\
\text { employee motivation }\end{array}$ & $\begin{array}{l}\text { Strengthening of participation, } \\
\text { promotion of team work, } \\
\text { adoption of brainstorming } \\
\text { accessions }\end{array}$ \\
\hline $\begin{array}{l}\text { 2. Strategy and } \\
\text { Planning }\end{array}$ & $\begin{array}{lr}\text { Target } & \text { setting, } \\
\text { implementation } & \text { of } \\
\text { Management by } & \\
\text { Objectives } & \end{array}$ & $\begin{array}{l}\text { Lack of information } \\
\text { from the part of } \\
\text { employees }\end{array}$ & $\begin{array}{l}\text { Elimination of information } \\
\text { gap, setting general and } \\
\text { specific goals }\end{array}$ \\
\hline $\begin{array}{l}\text { 3.Human } \\
\text { Resources }\end{array}$ & $\begin{array}{l}\text { Employees with high } \\
\text { qualifications, constant } \\
\text { education, mobilization }\end{array}$ & $\begin{array}{l}\text { Inexistence of a culture } \\
\text { of open } \\
\text { communication }\end{array}$ & $\begin{array}{l}\text { Promotion of constant and } \\
\text { continuous } \\
\text { (seminars, post graduate } \\
\text { programs etc.) }\end{array}$ \\
\hline $\begin{array}{l}\text { 4.External } \\
\text { Partnerships } \\
\text { and Resources }\end{array}$ & $\begin{array}{l}\text { Development } \\
\text { cooperation, realization of } \\
\text { objectives based on } \\
\text { specific budget }\end{array}$ & Lack of information & $\begin{array}{l}\text { Resource saving, recycling, } \\
\text { reduced use of air conditions }\end{array}$ \\
\hline 5. Proc & $\begin{array}{l}\text { Continuous improvement of } \\
\text { daily procedures }\end{array}$ & Bure: & $\begin{array}{l}\text { Improvement of procedures, } \\
\text { digitalization, interoperability }\end{array}$ \\
\hline $\begin{array}{l}\text { 6. Results for } \\
\text { customers } \\
\text { (employees) }\end{array}$ & $\begin{array}{l}\text { Internal character of the } \\
\text { Directorate, satisfying } \\
\text { service of employees }\end{array}$ & Bureat & $\begin{array}{l}\text { Simplification of procedures, } \\
\text { reduce of bureaucratic } \\
\text { obstacles }\end{array}$ \\
\hline $\begin{array}{l}\text { 7. Results for } \\
\text { Human } \\
\text { Resources }\end{array}$ & $\begin{array}{l}\text { Satisfying working } \\
\text { conditions }\end{array}$ & $\begin{array}{l}\text { Insufficient knowledge } \\
\text { of employees about the } \\
\text { goals of the } \\
\text { Directorate }\end{array}$ & $\begin{array}{l}\text { Propagations of the goals of } \\
\text { the Directorate, focus on } \\
\text { health and security of } \\
\text { employees, improvement of } \\
\text { working conditions }\end{array}$ \\
\hline $\begin{array}{l}\text { 8. Results for } \\
\text { Society }\end{array}$ & $\begin{array}{l}\text { High qualified employees, } \\
\text { sensitization for } \\
\text { environment and } \\
\text { disabled }\end{array}$ & $\begin{array}{l}\text { The actions of the } \\
\text { Ministry are not known } \\
\text { in the society, bad } \\
\text { relations with mass } \\
\text { media }\end{array}$ & $\begin{array}{l}\text { Continuous improvement for } \\
\text { society, quality function of the } \\
\text { Directorate, promotion of } \\
\text { good practices and actions, } \\
\text { creation of a communicative } \\
\text { policy }\end{array}$ \\
\hline $\begin{array}{l}\text { 9.Key } \\
\text { Performance } \\
\text { Results }\end{array}$ & $\begin{array}{l}\text { Setting specific targets, } \\
\text { implementation of target } \\
\text { setting, conservation of the } \\
\text { building }\end{array}$ & $\begin{array}{l}\text { Lack of necessary } \\
\text { infrastructure }\end{array}$ & $\begin{array}{ll}\text { Strengthening } & \text { of the } \\
\text { Directorate, } & \text { effective of } \\
\text { implementation } & \text { goals, of } \\
\text { Standardization } & \\
\text { procedures } & \end{array}$ \\
\hline
\end{tabular}

(Source: Administrative reports of the assessment team and the team of designed actions).

\section{The Outcomes of CAF Implementation}

The implementation of CAF in the Directorate of Human Resources of the Ministry of Administrative Reform and Electronic Governance was an opportunity for employees to come in touch with TQM tools. Despite the fact that not many changes have been made, this implementation brought only positive outcomes, without having any costs. First of all, CAF implementation had a diagnostic character, and for that reason, through the self-assessment process, the employees had a better image of the strengths and problems of the Directorate.

"The most important outcome of this implementation was the better understanding of the real problems of the Ministry. CAF helped us to make a self-assessment and to present how we work and if we are effective and provide quality services" (R.1). 
"With CAF implementation the employees by giving their opinion in questionnaires (which were anonymous), helped us find all our weaknesses and try to improve them" (R.3).

The whole process was automatic and self-centered. The employees of the Directorate participated in every stage of this implementation. Thus, the culture of the organization changed to be more cooperative.

"We created an atmosphere of team cooperation, where every employee felt that he offered to this implementation in order to improve and make our Directorate better and more quality oriented" (R.3).

Furthermore, the employees learned for their first time about TQM significance and quality issues in management. In public sector, where bureaucratic procedures create obstacles in the daily service of citizen, the introduction of quality methods in processes would be an innovation and major advantage towards the simplification of procedures and the provision of better and faster services to citizens.

"The basic advantage was the diagnosis of the strengths and weaknesses, the detection of problems faced by the Directorate and the familiarization of employees participated with quality concepts" (R.10).

The most designed actions were general and oriented in the object of the Directorate, which is Human Resources. The most important action was the creation of an electronic database, where all the employees' personal files were kept there, so that anyone could easy find the information he wants. Instead, before the implementation of CAF, all the files had been kept in physical form and as a result many of them had been lost or difficult to find them.

"An electronic database has been created, which consists of all the personal qualifications of employees, theirs reports, their assessments and in general their personal files. This was an important innovation, since in most Directorates of other Ministries the register of employees exists only in physical form" (R.2).

Another new procedure, especially for a public organization, was the electronic submission of leaves. The Directorate created a special website, where employees could electronically submit their leave and their supervisor approve it.

"An electronic website was created for the submission of the leaves of employees. With this innovation, every employee using his personal username and password can easy submit his leave and see if it is approved or not. Furthermore he is able to see the rest of his leaves. By this way, procedures are simpler, control is easier and employees are better and faster serviced" (R.9).

Finally, CAF implementation helped supervisors improve their relations with employees. Also, there has been an effort in saving resources through recycling and secure employees' health.

"The leadership improved its communication with the employees. We tried to save resources through recycling or reducing the use of air conditioners. We introduced a new database with the personal electronic register of each employee. We tried to satisfy human resources through the care for their health and we moved on the control of the building for cadmium and amianthus" (R.7).

The most designed actions have not been realized, because of the diagnostic character of the implementation, the lack of time, financial resources and support from the superior echelons and the constant hierarchical and political changes, which have set an unstable environment.

"A lot of actions had been designed, but were general, non-targeted and as a result they have not been realized. The reasons are the difficulties in understanding this model, the lack of information and time to design and apply these actions, the lack of financial resources and the lack of support from the higher levels of administration" (R.3).

“..We had a lot of changes in hierarchical pyramid and there hasn't been continuity in leadership" (R.4).

"..The reason is the little or no time we had for the design of these actions, the constant changes in the hierarchy, the political turbulence caused by the economic crisis, which didn't permit to promote our work" (R.5).

The design of specific actions is not an easy case. Leadership should be supportive, resources should be available and an atmosphere of organizational changed should exist. The constant political changes in the Greek Government, which had as a result the changes in the hierarchical pyramid of each Ministry, did not facilitate the design of specific actions. However, the implementation of CAF brought a lot of positive outcomes, as analyzed before, and was definitely a way improving the functions of the Directorate, in the years to come. 


\section{Usefulness of CAF}

All the respondents agreed about the usefulness of CAF and its offer to the improvement of services in the Public Sector. CAF is an economic and useful tool, which doesn't need extra financial and human resources to be implemented, since the human resources of the organizations provide this task. Through the self-assessment process, employees write down the strengths and weaknesses of their organization, according to their daily experiences, and try to find actions in order to eliminate problems and to empower their advantages.

"CAF is a useful, economic, friendly tool that can help public organizations to improve their services and contribute to a constant administrative improvement. It can eliminate some of the basic problems faced in the Greek public sector such as the bureaucratic procedures. The self-assessment of the CAF is an assessment based on real elements, recognized by the employees of the organization. Through scoring the criteria, we give a direction that the organization should follow in order to improve its activities, and we present good practices, which can be useful for the elimination of problems faced by other organizations" (R.10).

As far as the propagation of CAF in the Greek Public Administration is concerned, the respondents feel that the outcomes of each implementation should be widely spread, so that other organizations learn about CAF and implement it. For that reason, the use of electronic instruments, Internet should be used so that CAF be widely known.

"CAF could be known via organizations' websites, through the promotion of best practices and advantages of its implementation" (R.10).

"The most important is to present the outcomes of each implementation in the Greek public administration in order to be followed by other organizations" (R.6).

Since many European Public Organizations have been successfully implemented CAF, the Greek Public Sector should take this chance for the elimination of the problems faced and the provision more quality oriented services, through the exchange of experiences with European Agencies.

"CAF is a tool that is most known in the European public services. I think that the best solution for its expansion is the exchange of experiences with other European services that have managed to implement CAF effectively" (R.2).

However, most of the respondents think CAF as a utopia, since Greece faces a lot of problems in the political and economic field. The present period is rough enough for the Greek Public Administration and any TQM tools would be difficult to be implemented. The assessment of public servants, the gradual loss of their tenure and the establishment of the single payment have made difficult the application of any new innovation method. Furthermore, the period in which Interviews were taken, was a pre- elections period, with an atmosphere of instability.

“..it is a difficult period that we cannot only talk for the contribution of CAF but we have to see more important problems, which derive from the economic crisis and the lack of stability in the basic institutions in our country" (R.3).

"CAF is an important TQM tool that is economic and easy to use. However, due to the problems faced in Greek Public Administration, the economic crisis and the political turbulence (presidential and national elections), such tools are difficult to be implemented and promoted (R.8)".

CAF gives the chance to organizations to discover their internal and external environment, thus contributing to the increased understanding of its problems (Thijs and Staes, 2005). Therefore, the Directorate of Human Resources, in this first implementation, has managed to write down its weaknesses and find its strengths, in order to be more efficient and productive. The first pilot implementation of CAF in the Ministry, despite the difficulties referred previously, was enough satisfying, so that the Directorate of Human Resources was one of the candidate organizations for the National Quality Award in $2007^{3}$, during the first Quality Session for Public Administration, where the Directorate received praise from the Minister of the Interior for its participation. Concluding, the main views of the participants about the most important issues of the CAF implementation are presented in the following table.

\footnotetext{
${ }^{3}$ www.gspa.gr(date of last access: 13/2/2015)
} 


\begin{tabular}{|c|c|c|c|c|c|c|}
\hline R/Is. & Reasons for implementation & Difficulties & Advantages & $\begin{array}{l}\text { Reasons for Non } \\
\text { realizing } \\
\text { actions }\end{array}$ & Achievements & Usefulness \\
\hline R1 & $\begin{array}{l}\text { Upgrade of } \\
\text { functions }\end{array}$ & Understanding the criteria & $\begin{array}{l}\text { Understanding } \\
\text { the real } \\
\text { problems }\end{array}$ & $\begin{array}{l}\text { Lack of time } \\
\text { and interest }\end{array}$ & Auto diagnosis & $\begin{array}{l}\text { Useful but difficult to } \\
\text { implement }\end{array}$ \\
\hline $\mathbf{R 2}$ & Introduction of Quality & Lack of time for education & $\begin{array}{l}\text { Tracking of } \\
\text { strengths/weaknesses, } \\
\text { Motivation }\end{array}$ & Lack of time & $\begin{array}{l}\text { Better } \\
\text { understandingoffunctions }\end{array}$ & Useful \\
\hline $\mathbf{R 3}$ & $\begin{array}{l}\text { Upgrade of } \\
\text { functions, } \\
\text { Strengthen HR }\end{array}$ & $\begin{array}{l}\text { The unknown } \\
\text { of the tool }\end{array}$ & $\begin{array}{l}\text { Team } \\
\text { participation, } \\
\text { Recognition of problems }\end{array}$ & $\begin{array}{lr}\text { Lack } & \text { of } \\
\text { information } & \text { and } \\
\text { time } & \end{array}$ & Image Improvement & $\begin{array}{l}\text { Useful, Friendly, } \\
\text { Economic, } \\
\text { Easy }\end{array}$ \\
\hline R4 & $\begin{array}{l}\text { Change of culture, } \\
\text { Upgrade of functions }\end{array}$ & Understanding the Criteria & $\begin{array}{l}\text { Team } \\
\text { Understanding of the } \\
\text { functions }\end{array}$ & $\begin{array}{lr}\begin{array}{l}\text { Changes } \\
\text { hierarchy, } \\
\text { of time }\end{array} & \end{array}$ & $\begin{array}{l}\text { Introduction } \\
\text { of new } \\
\text { procedures }\end{array}$ & Efficient, Effective \\
\hline $\mathbf{R 5}$ & Introduction of Quality & $\begin{array}{l}\text { Lack of } \\
\text { previous experience }\end{array}$ & $\begin{array}{ll}\text { Understanding } & \text { how } \\
\text { Directorate works } & \end{array}$ & $\begin{array}{l}\text { Lack of time, } \\
\text { Political } \\
\text { turbulence }\end{array}$ & $\begin{array}{l}\text { Experience, learning quality } \\
\text { concepts }\end{array}$ & Useful, Economic \\
\hline R6 & $\begin{array}{l}\text { Introduction } \\
\text { of Quality }\end{array}$ & Lack of time and experience & $\begin{array}{l}\text { Diagnosis of } \\
\text { strengths/ weaknesses, } \\
\text { Team spirit }\end{array}$ & $\begin{array}{l}\text { Lack of time } \\
\text { and support }\end{array}$ & $\begin{array}{l}\text { Better } \\
\text { Understanding of problems }\end{array}$ & Helpful, Economic \\
\hline R7 & $\begin{array}{l}\text { Upgrade of } \\
\text { functions, Introduction } \\
\text { of quality }\end{array}$ & $\begin{array}{l}\text { Understanding the Criteria } \\
\text { and way of } \\
\text { scoring }\end{array}$ & $\begin{array}{l}\text { Team spirit, } \\
\text { Understanding } \\
\text { the real } \\
\text { problems }\end{array}$ & $\begin{array}{l}\text { First time } \\
\text { of } \\
\text { implementation, } \\
\text { no previous } \\
\text { experience }\end{array}$ & $\begin{array}{l}\text { Introduction } \\
\text { of TQM tool }\end{array}$ & $\begin{array}{l}\text { Friendly, } \\
\text { Economic, } \\
\text { Helpful }\end{array}$ \\
\hline R8 & $\begin{array}{l}\text { Introduction } \\
\text { of TQM, } \\
\text { Improvement } \\
\text { of functions }\end{array}$ & Lack of time and education & $\begin{array}{l}\text { Upgrade } \\
\text { of functions, Team spirit }\end{array}$ & $\begin{array}{l}\text { Changes in } \\
\text { Hierarchy, } \\
\text { Political changes }\end{array}$ & $\begin{array}{l}\text { Diagnosis } \\
\text { of functions }\end{array}$ & $\begin{array}{l}\text { Useful, } \\
\text { Costless }\end{array}$ \\
\hline R9 & $\begin{array}{l}\text { Upgrade of } \\
\text { functions }\end{array}$ & $\begin{array}{l}\text { Understanding Criteria and } \\
\text { way of scoring }\end{array}$ & $\begin{array}{l}\text { Diagnosis of } \\
\text { functions, Introduction of } \\
\text { Quality }\end{array}$ & $\begin{array}{l}\text { Lack of time } \\
\text { and support }\end{array}$ & $\begin{array}{l}\text { New } \\
\text { Modernization, } \\
\text { procedures, Introduction } \\
\text { of Quality }\end{array}$ & $\begin{array}{l}\text { Useful, Important for } \\
\text { Improvement } \\
\text { ofservices }\end{array}$ \\
\hline R10 & $\begin{array}{l}\text { Identification of strengths } \\
\text { /weaknesses }\end{array}$ & $\begin{array}{l}\text { Understanding the criteria } \\
\text { and way of scoring }\end{array}$ & $\begin{array}{l}\text { Diagnosis of strengths } \\
\text { weaknesses, Introduction } \\
\text { of quality }\end{array}$ & $\begin{array}{l}\text { Lack of } \\
\text { time, support and } \\
\text { financial } \\
\text { resources }\end{array}$ & $\begin{array}{l}\text { Provision of quality } \\
\text { services }\end{array}$ & $\begin{array}{l}\text { Useful, } \\
\text { Economic, } \\
\text { Friendly }\end{array}$ \\
\hline
\end{tabular}

\section{Discussion and Conclusion}

The implementation of CAF in the Greek Public Administration constitutes a great organizational change in today's complex environment. According to CAF driver, an organizational change is not an automatic procedure; instead, a business program should be created and implemented step by step, so that the implementation of CAF would be successful (CAF, 2007). 
From the implementation of CAF in the Directorate of Human Resources in the Ministry of Administrative Reform and Electronic Governance, in 2007, a lot of weaknesses have been appeared, mostly in the preparation process. CAF was a new tool that had to be immediately implemented, with insufficient education and with lack of information. No business plan or policy had been created, so that CAF could be implemented based on specific targets. In contrast, the first implementation was fast, convenient, and only managed to investigate some of the strengths and weaknesses of the Directorate, without setting specific measures or facing the dysfunctions of the Ministry. The designed actions were general, not clear and hazy, while most of those didn't connect with the treatment of specific weaknesses of the Directorate. In contrast, a general application had been realized, like a test, without a substantial connection with the daily functions of the Directorate, thus limiting the possibility of improvements and utilities.

The difficulties detected, appeared mostly because of the load of work of the employees, and as a result the members of the assessment team didn't have the time demanded for the excellent implementation of CAF. The advantages raised, concerned mostly the diagnosis of the strengths and weaknesses of the Directorate and the better understanding of the way of its functions. The paradox here is that while the CAF implementation helped for the clear specification of the strengths and weaknesses of the Directorate, it didn't lead to the addressing of realistic targets. Therefore, the diagnosis of the functions did not help enough for the quality improvement of targets and designed actions of the Directorate, and as a result the model did not respond to the objectives that it poses, according to CAF driver.

CAF could be a start for the creation of an overall quality framework in the Ministry and in the totality of Public Administration, since it contributes to the introduction of TQM tools in the public sector and to the provision of quality services to citizen. However, eight years after this implementation, no significal change has been made towards quality matters. Furthermore, CAF is not widely spread to other public organizations, and no one seems to care about the outcomes of this effort.

The positive outcomes of this implementation were the realization of the need for actions, so that procedures are more simplified, and bureaucratic obstacles are eliminated. Through the introduction of new electronic systems in the Directorate (electronic submission of leaves, electronic register), procedures have been simplified, the load of work has been reduced, employees are more satisfied and the Directorate became more effective and efficient in contrast to other Directorates.

For a successful implementation of CAF, a suitable culture should exist. An organizational culture with common values, admissions and views would lead to an easier introduction of any change. Through the creation of the appropriate culture, employees will come closer to the significance of quality, which will be courted every day from all the employees and all the departments. CAF's purpose is not only to bring the organization closer to the values of TQM, but to bring these values closer to the overall culture of the organization (Thijs and Staes, 2010).

According to the respondents, as far as the future of CAF is concerned, they seemed to be uncertain and troubled to answer. The present political evolutions, the uncertainty about the future of the country and its currency, the changes that tend to restrict public sector, the loss of money and the social crisis, made difficult any discussion or promotion of CAF. This appears a utopia, according to most respondents. Indeed, one of the participants, critically said:"How can you ask about CAF's future, the moment we do not know our own future?"

For an effective implementation of CAF, an institutional consolidation and a wide promotion in the public sector are demanded. More specifically, the creation of a quality policy, in which CAF will be included, is necessary. Also, the repetition of the implementations is imposed, so that weaknesses are faced more effectively and members understand better the content and the values of CAF. The CAF's future does not only depend on the present crisis, but on the total number of CAF users and on the engagement of the political authorities to support and promote this tool.

The quality of the state and the quality of democracy, which lead to the quality of the life of the citizens, are major challenges for the modernization of the country. TQM models and tools could contribute to the attainment of quality and to the improvement of effectiveness and efficiency of public organizations. This overall operation, is not an automatic procedure, but it needs time, willingness, patience and support from the political leadership, so that the excellent outcomes for the administration and the democracy are achieved.

As Aristotle said: "Excellence is never an accident. It is always the result of high intention, sincere effort, and intelligent execution; it represents the wise choice of many alternatives - choice, not chance, and determines your destiny." 


\section{References}

Argyriades, D., 2013. Greek Exit from crisis: A pressing and much needed public service reform, Social Sciences, 1(2): 78-90.

Asim, M., 2001. Adopting quality management public service reform, Labour and management in development, 2(6): $1-19$.

Beltrami, G., 1992. Quality and Public Administration,Economics and Law of the tertiary, 3(4): 669-781.

Berk, J., Berk, S., 1993.Total Quality Management: Implementing Continuous Improvement. New York: Sterling Publishing Co.

Chandler, J., 2003. Comparative Public Administration. Athens: Papazisis.

Dearing, E., Staes, P., Prorok, T., 2006. CAF works- Better service for the citizens by using CAF. Austrian Federal Chancellery, Directorate General III, Civil Service \& Administrative Reform. Ferdinand Berger \& Sohne, Austria.

Doherty, T. L., Horne, T. (2002), Managing Public Services - Implementing Changes, A thoughtful approach to the practice of management, Routledge, London.

Engel, C. 2002.Common Assessment Framework: The State of Affairs, Maastricht: EIPASCOPE.

European Institute of Public Administration (EIPA), 2013. Caf 2013- Improving Public Organization through Self Assessment, 2013 edition. Available at: http://www.eipa.eu/files/File/CAF/CAF_2013.pdf (date of last access: 28 January 2015).

Ferlie, E., Pettigrew, A., 1996. The New Public Management in Action. United Kingdom: Oxford University Press.

Gilligan, P, Mandy, M., 2008. The Common Assessment Framework: does the reality match the rhetoric? Child and Family Social Work, 13(2): 177-187.

Hitiris, L., 2001. Organizational Behavior: The human behavior in organizations and businesses (in Greek). Athens: Interbooks.

James, P., 1996. Total Quality Management. London: Prentice Hall.

King, N., Horrocks, C., 2010.Interviews in qualitative research. London: Sage.

Mc Cabe, D., Wilkinson, A., 1997. The rise and fall of TQM: The vision, meaning and operation of change, Industrial Relations Journal, 29(1): 18-29.

Ministry of Interior-General Secretariat of Public Administration and Electronic Governance, 2007. Common Assessment Framework (in Greek). Athens: National Printing House.

Ministry of Interior-General Secretariat of Public Administration and Electronic Governance, 2009. Driver of Implementation of Common Assessment Framework (in Greek). Athens: National Printing House.

Passas, P., 2010. Texture of Instruments about Public Management in the Greek Public Administration (in Greek). Athens: National School of Public Administration.

Psychogios, G. A., 2007. Qualitative Research on Managers' awareness of TQM: Understanding TQM in context: Aspects in the Greek Service Industry,The Qualitative Report, 12(1): 40-66.

Richie, J., Lewis, J., 2003. Qualitative Research Practice: a guide for social science students and researchers. London: Sage.

Rickards, R. C., Ritsert, R., 2013. Self Assessment for Improving Public Sector Performance: The EUs CAF, International Journal of Business and Public Administration, 10(2): 135-151.

Sorensen, E., Torfing, J., 2012. Collaborative Innovation in the public sector, The Innovation Journal: The Public Sector Innovation Journal, 17(1):1-14.

Stringham, S. H., 2004. Does Quality Management Work in the Public Sector, Public Administration and Management: An interactive Journal, 9(3): 182-211.

Thjis, N., Staes, P., 2005. Report on the State Affairs of the Common Assessment Framework after five years. Maastricht:EIPASCOPE.

Thjis, N., Staes, P., 2010. From Self-Assessment to External Feedback-Labeling, , Maastricht: EIPASCOPE.

Tsimboukidou, I., Dionysopoulou, P., Mylonakis, J., 2013. Total Quality Management Systems in the Hellenic Public, Public Administration Research, 2(2): 124-133.

Tsiotras, G., 2002. Quality Improvement (in Greek). Athens: Benos. 